Столяренко А. М.

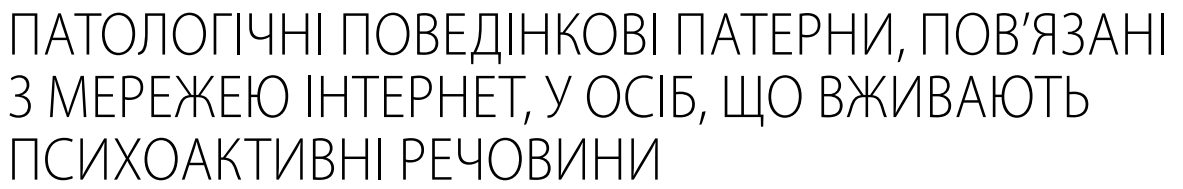

Запорізький державний медичний університет, Україна

Stolyarenko A. N.

\title{
PATHOLOGICAL BEHAVIORAL PATTERNS RELATED TO THE INTERNET IN A PERSON WHO USE PSYCHOACTIVE SUBSTANCES
}

Zaporizhzhya State medical University, Ukraine

Резюме. Залученість осіб, що вживають психоактивні речовини в інтернет-користування, накладає на них певні поведінкові зміни. Поєднання психопатологічного предиспозиційного фону у вигляді емоційно-вольових порушень з феноменами, властивими поглибленому використанню мережі Інтернет, зумовлює розвиток у осіб досліджуваної групи специфічних поведінкових патернів, пов'язаних з інтернет-користуванням. Мета дослідження - дослідити і систематизувати патологічні поведінкові патерни, пов'язані з мережею Інтернет, у осіб, що вживають психоактивні речовини.

Матеріал і методи дослідження. Для реалізачії поставленої мети дослідження було проведено контент-аналіз наукової літератури та матеріалів $3 \mathrm{MI}$, а також обстежено 34 людини з психічними та поведінковими розладами внаслідок вживання психоактивних речовин (F19.2).

В результаті дослідження виділені і описані п'ять патологічних поведінкових патернів, пов'язаних з мережею Інтернет у осіб, що вживають психоактивні речовини: редукція оffline комунікації і надання переваги online дозвіллю, висвітлення у мережі Інтеренет власних асоціальних вчинків, зміна адиктивної пошукової активності $з$ offline середовища на мережу Інтернет, аутоіндукування крайніх перепадів настрою за допомогою інтернет-контенту та індукування інтернет-контентом крайніх варіантів поведінки.

Висновки. Інтернет-користування здатне приводити до специфічної патологічної модифрікачії поведінки осіб, що вживають психоактивні речовини. Виявлені поведінкові патерни можуть зумовлювати наростання соціальної дезадаптації і виступати потенціюючим і підтримуючим фактором наркотизачії.

Ключові слова: Інтернет, інтернет-користування, інтернет-залежність, залежність від психоактивних речовин, поведінкові патерни.

Вступ. Останніми десятиріччями спостерігається розширення ролі мережі $\mathrm{IH}^{-}$ тернет у повсякденному житті громадян. Перенесення до мережі Інтернет окремих компонентів соціальної взаємодії у рамках роботи та дозвілля призвело до формування «віртуальної середи проживання», яка нагадує реальний соціум, а часом заміщує його, залучаючи до інтернет-користування все більше громадян [12]. Так, вже сьогодні більшість осіб підліткового та молодого віку у розвинених країнах та країнах, що розвиваються, $\epsilon$ щоденними користувачами мережі Інтернет [15].

Інтернет-користування здатне призводити до модифікації поведінкових патернів 
користувачів [16]. Згідно багатьох досліджень, зміна емоційних та поведінкових патернів внаслідок поглибленого інтернет-користування здатна чинити негативний вплив на повсякденне життя користувачів $[4,14]$.

3 найбільш відомих модифікацій поведінки під впливом мережі Інтернет $\epsilon$ інтернет-залежність та суїцидальна поведінка. Групою ризику розвитку вказаної патологічної поведінки виступають підлітки [17].

Існують окремі вказівки на збіднення кругу інтересів, соціального функціонування, розвиток сімейної дезадаптації та депресії внаслідок поглибленого інтернет-користування. Таким змінам піддаються не лише підлітки і молоді люди, а й особи середнього віку [16].

В контексті питання інтернет-асоційованих поведінкових змін окрему увагу привертають особи, залежні від вживання психоактивних речовин. Користування мережею Інтернет накладає відбиток на емоційний стан та поведінку користувачів, очікувано виразним цей вплив $\epsilon$ на категорію громадян, які вже мають емоційно-вольові порушення - залежних від вживання психоактивних речовин [6]. Втім, особливості поведінкових модифікацій внаслідок інтернет-користування у осіб, які вживають психоактивні речовини, залишаються не розкритими.

Мета дослідження - дослідити та систематизувати патологічні поведінкові патерни, пов'язані з мережею Інтернет, у осіб, що вживають психоактивні речовини.

Матеріал та методи дослідження. Проведено контент-аналіз наукової літератури та матеріалів 3MІ за темою дослідження. Додатково проведене клініко-психопатологічне та медико-психологічне обстеження 34 осіб, хворих на психічні та поведінкові розлади, внаслідок поєднаного вживання психоактивних речовин (F19.2), середній вік у групі становив $25 \pm 0,62$ років. У коло вживаних хворими психоактивних речовин входило різне співвідношення опіоїдів, галюциногенів, психостимуляторів, седативних препаратів, в тому числі алкоголь.
Результати та їх обговорення. Контент-аналіз наукової літератури та 3МІ дозволив нам виділити наступні патологічні поведінкові патерни, пов'язані з мережею Інтернет, у осіб, що вживають психоактивні речовини:

1. Редукція offline комунікації і надання переваги online дозвіллю. У осіб із залежністю від психоактивних речовин часто діагностуються різні форми аутоізоляції внаслідок певних особливостей особистості, психопатологічних станів або соціальної дезадаптації. Дистанціювання від суспільства у даних осіб часто заміщується Інтернет-активністю [2]. Можна виділити декілька варіантів етіолоічно-обумовленого Інтернет-користування у осіб, що вживають психоактивні речовини.

А) Надання переваги віртуальному світу на шкоду живому спілкуванню, як варіація ескапізму. Найчастіше передумовами розвитку такого варіанту $\epsilon$ неприйняття та незадоволеність існуючою дійсністю, небажання підтримувати чи налагоджувати соціальні зв'язки, десоціалізація, внутрішня потреба відсторонення від соціуму та об'єктивної реальності, протестна поведінка; рідше - підсвідомо впроваджуваний спосіб аутопокарання. Інтернет-користування у даному випадку носить «збіднений» харакер і зводиться до одноманітного дозвілля зазвичай «поверхневої», «фізіологічної» гедоністичної спрямованості; таким особам притаманний розвиток ігрової інтернет-залежності, відео-інтернет-залежності. Даний варіант виступає у якості дестабілізуючого фактора особистості, здатен призводити до психопатизації особи та поглиблення соціальної ізоляції.

Б) Заміна живого спілкування підвищеною Інтернет-соціальною взаємодією як варіант аутокурації. Передумовами даного варіанту $\epsilon$ соціальна дезадаптація особи при наявності внутрішньої портеби та бажання у підтримці соціальних контактів. Соціальна ізоляція особи часто носить вимушений характер, ініційований у більшій мірі не самою особою, а ії оточенням. В цьому випадку живе міжособистісне спілкування у осіб 
із залежністю на психоактивні речовини заміщується спілкуванням у віртуальному просторі. Інтернет-користування у даному випадку є різноманітним і часто поєднаним із творчістю - написанням віршів, малюванням тощо. Від соціалізуючої поведінки даний варіант відрізняє псевдоактивний, непродуктивний характер дій та/чи їх негативний вплив на життєдіяльність особи.

2. Висвітлення у мережі Інтеренет власних асочіальних вчинків. Останнім часом інтернет-простір, особливо соціальні мережі, стали використовуватися як майданчик для сповіщення соціуму про власні асоціальні дії чи наміри: від публікації відеозапису вбивства до розміщення опису самовбивста. Найчастіше такі дії вчиняються особами залежними від психоактивних речовин або у стані сп'яніння.

Зміна стану свідомості, емоцій та волі під час алкогольної чи наркотичної інтоксикації часто провокують «натхнення» поділитися 3 іншими чимость таємним, тоді як мережа Інтернет уособлює ідеального «слухача» для таких сповідей, тому в мережі Інтернет можна побачити зізнання у власних злочинах, навіть вбивстві, які правопрушники публікують власноруч у стані сп'яніння [1].

Стан інтоксикації психоактивними речовинами може виступати в якості «поштовху» до суїцидального рішення, а мережа Інтернет - місцем сповіщення про таке бажання. У синтонних, конформних і істероїдних особистостей алкогольне та наркотичне сп'яніння виступає каталізатором традиційних ритуальних дій, що передують самогубству: прощальні записки, переодягання в спеціально підготовлений одяг, прослуховування улюбленої музики; до таких дій останнім часом все частіше виступає викладання «прощальних постів» у соціальних мережах [13].

3. Зміна адиктивної пошукової активності з оffline середовища на мережу Інтернет. Залежні від психоактивних речовин особи останнім часом нерідко використовують мережі Інтернет як ареал 3 купівлі наркотичних речовин. Можливість анонімної взаємодії продавця та покупця за допо- могою мережі Інтернет та безконтактність фінансових операцій дозволили перенести наркоторгівлю у інтернет-простір, що не тільки спростило доступ осіб до наркотичних речовин, виступаючи фактором індукції та підтримки наркотизації, й розширило спектр вживаних особами психоактивних речовин, призводячи до полінаркоманії, але й змінило пошуково-поведінкові патерни осіб, залежних від психоактивних речовин 3 реального середовища на інтернет-простір $[3,11]$.

4. Аутоіндукування крайніх перепадів настрою за допомогою інтернет-контенту.

5. Індукування інтернет-контентом крайніх варіантів поведінки. Внаслідок того, що емоційно-вольова сфера осіб, які страждають на залежність від психоактивних речовин вже є ушкодженою, наявний у мережі Інтернет подразник, який не призведе до зміни настрою чи поведінки психічно здорової людини, у осіб із залежністю від психоактивних речовин, як у осіб із іншими психічними порушеннями, здатен призвести до непередбачуваних результатів. Таку поведінку можна розділити на два варіанти: гостру та пролонговану.

А) Гостра індукована інтернет-контентом поведінка. Найчастіше виникає у стані гострої інтоксикації психоактивною речовиною. Стан сп'яніння від психоактивних речовин може сприяти реактивації хворобливих переживань, перебільшенню глибини кризової ситуації, надання їй характеру безвиході, провокувати більш легке виникнення різних афективних і імпульсивних реакцій у відповідь на незначний психогенний вплив. Часто таким впливом стає інтернет-контент: «влучні» строки пісні або вірша можуть спровокувати у особи спонтанну думку про марність свого життя та необхідність певних дій. У зв'язку з цим, невірно інтерпретовані у стані сп'яніння дописи у соціальних мережах можуть спонукати висновок про «невірність» подружжя та стати індуктором внутрішньо-сімейних криз [7, 10]. При цьому контент-індуктор зазвичай не відповідає суті індукованої ним поведінки і провокує їі нецілеспрямовано та спонтанно; індукована 
поведінка емоційно обумовлена, імпульсивна, малоосмислена, швидкоминуча.

Б) Пролонгована поведінка, індукована інтернет-контентом. Особи, що вживають психоактивні речовини, зазвичай відрізняються зниженням толерантності до стороннього впливу. Не рідко індуктором такого впливу виступає інтернет-контент. Тож особи, що вживають психоактивні речовини, схильні переймати загальний емоційний фон та індукуючі твердження з соціальних мереж, аудіо- та відео-інтернет-контенту. Так, існують вказівки на підвищену схильність до неадекватних та деструктивних емоційних та поведінкових реакцій серед підлітків та осіб із лабільною психікою при їх залученні до гри у інтернет-ігри та перегляду відео-контенту із насиченими сценами насильства, а також на зростання випадків суїциду серед підлітків, які вживають психоактивні речовини й одночасно з цим перебувають у інтернет-спільнотах «групи смерті» $[5,8,9]$. Чим більше пролонгованим $\epsilon$ отримання емоційно схожої інформації, тим стабільнішим і глибшим $\epsilon$ викривлення поведінки індукованої ооби аж до надбання патоперсонологічних рис [14].

При цьому зміст контенту-індуктора в цілому відповідає індукованому стану, інформація отримується особою переважно не в стані сп'яніння, а навпаки, провокує у особи бажання вжити психоактивну речовину з аутокураційною метою. Більш індукуючою для осіб, залежних від психоактивних речовин, $є$ інформація з негативним емоційним фоном, в якій рефреном стверджується про сумність, марність, безглуздість та тяжкість існування, робиться акцент на смутку та несправедливості в житті, негативник якостях людей.

Висновки. Під впливом певного інтернет-контенту користувачі, які вживають психоактивні речовини, здатні вдатися до такої поведінки, яку 6 не реалізували за умов недоступу до мережі Інтернет. Інтернет-інформація для даної категорії громадян може виступати індуктором асоціальної поведінки, а соціальні інтернет-платформи - ще більше посилювати соціальну дезадаптацію.

Таким чином, можна дійти висновку, що використання мережі Інтернет особами із залежністю від психоактивних речовин, здатне змінювати їх емоційний стан та поведінку. Але досі не можна однозначно вказати, позитивно чи негативно інтернет-користування впливає на осіб, залежних від психоактивних речовин. Такі впливи мережі Інтернет залишаються до кінця не дослідженими і потребують подальшого вивченя.

\section{СПИСОК ЛІТЕРАТУРИ}

1. Артем Исхаков письмо, полный текст. Режим доступа: http://skuky.net/140511.

2. Бердин Р. Д. Социальная отрешенность как предиктор интернет-аддиктивного поведения // Инновационная наука. 2015. № 1, 2. С. 267-268.

3. Бикеева Е. С. Незаконный оборот наркотиков в Интернете // Пробелы в Российском законодательстве. Юридический журнал. 2011. № 6. С. 240-241.

4. Дрепа М. И. Интернет-зависимость как предмет научной рефлексии в современной психологии // Знание. Понимание. Умение. 2009. № 2. С. 189-191.

5. Жихарева Л. В. Виртуальные группы смерти: методология исследования // Научные ведомости Белгородского государственного университета. Серия: Гуманитарные науки. 2018. № 37 (1). С. 161-168.

6. Козлова Н. С. Влияние интернет-среды на личность и её жизнедеятельность // Знание. Понимание. Умение. 2015. № 3. C. 275-276.

7. Ласый Е. В., Новодворская М. В., Евсегнеев Р. А. Анализ предсмертных записок и протоколов расследования по факту суицида: связь факта употребления алкоголя и анамнеза злоупотребления алкоголем с триггерами и мотивами суицида // Социальная и клиническая психиатрия. 2012. № 4. С. 57-62.

8. Митягин С. А. Исследование социальных сетей Интернет на предмет выявления сопутствующих интересов лиц, склонных к наркомании // Международный научно-исследовательский журнал. 2012. № 6 (6). С. 59-64. 
9. Михайловская Н. В. Сочетанное потребление психоактивных веществ больными опийной наркоманией с суицидальным поведением // Тюменский медицинский журнал. 2014. № 1. С. 14-15.

10. Сахаров А. В., Говорин Н. В. Суицидальное поведение и потребление алкоголя: оценка взаимосвязей на популяционном уровне // Суицидология. 2015. № 1, 2 (18, 19). С. 35-42.

11. Фадеева С. В. Компьютерная зависимость как фактор риска развития агрессивного поведения у подростков // Вестник Костромского государственного университета. 2010. № 5. С. 250-251.

12. Ходенкова Э. В. Интернет вещей как системный фактор интеграции физической, цифровой и виртуальной сред обитания человека // Манускрипт. 2018. № 10 (96). С. 97-98.

13. Школьники, которые устроили стрельбу по полицейским в Псковской области, а потом покончили с собой, незадолго до трагедии опубликовали прощальные посты в Интернете. A0 Telekompaniya NTV. Режим доступа: https://www.ntv.ru/ novosti/1702577.

14. Cerniglia L., Zoratto F., Cimino S., Laviola G., Ammaniti M., Adriani W. Internet Addiction in adolescence: Neurobiological, psychosocial and clinical issues // Neurosci Biobehav Rev. 201776 (A). P. 174-184.

15. Chérif L., Ayedi H., Hadjkacem I., Khemekhem K., Khemekhem S., Walha A., Kossentini I., Moalla Y., Ghribi F. Problematic Internet use among teenagers in Sfax, Tunisia // Encephale. 2015. № 41 (6). P. 487-492.

16. Kraut R., Patterson M., Lundmark V., Kiesler S., Mukopadhyay T., Scherlis W. Internet paradox. A social technology that reduces social involvement and psychological well-being? // Am. Psychol. 1998. № 53 (9). P. 1017-1031.

17. Marchant A., Hawton K., Stewart A., Montgomery P., Singaravelu V., Lloyd K., Purdy N., Daine K., John A. A systematic review of the relationship between internet use, self-harm and suicidal behaviour in young people: The good, the bad and the unknown // PLoS One. 2017. № 12 (8). e0181722. doi: 10.1371/journal.pone.0181722.

\section{PEЗЮME \\ ПАТОЛОГИЧЕСКИЕ ПОВЕДЕНЧЕСКИЕ ПАТТЕРНЫ, СВЯЗАННЫЕ С СЕТЬЮ ИНТЕРНЕТ У ЛИЦ, УПОТРЕБЛЯЮЩИХ ПСИХОАКТИВНЫЕ ВЕЩЕСТВА}

Столяренко А. Н.

Запорожский государственный медицинский университет, Украина

Вовлеченность лии, употребляющих психоактивные вещества в интернет-пользование, налагает на них определенные поведенческие изменения. Совмещение психопатологического предиспозичионного фона в виде эмочионально-волевых нарушений с феноменами, присущими углубленному использованию сети Интернет, предопределяет развитие у лии исследуемой группы спечифических поведенческих паттернов, сопряженных с интернет-пользованием.

Цель исследования - исследовать и систематизировать патологические поведенческие паттерны, связанные с сетью Интернет, у лии, употребляющих психоактивные вещества.

Материал и методы исследования. Для реализации поставленной чели исследования был проведен контент-анализ научной литературы и материалов СМИ, а также об- следованы 34 человека с психическими и поведенческими расстройствами вследствие употребления психоактивных веществ (F19.2).

В результате исследования выделены и описаны пять патологических поведенческих паттернов, связаных с сетью Интернет у лии, употребляющих психоактивные вещества: редукция offline коммуникачии и предпочтение online досуга, освещение в сети Интеренет собственных асоциальных поступков, изменение аддиктивной поисковой активности с оffline среды на Интернет, аутоиндучирования крайних перепадов настроения с помощью интернет-контента и индуцирования интернет-контентом крайних вариантов поведения.

Выводы. Інтернет-пользование способно приводить к специфической патологической модификации поведения лич, употребляющих психоактивные вещества. Выявленные поведенческие паттерны могут обуславливать нарастание социальной дезадаптации и выступать потенцирующим и поддерживающим фактором наркотизации.

Ключевые слова: Интернет, интернет-пользование, интернет-зависимость, зависимость от психоактивных веществ, поведенческие паттерны. 


\section{SUMMARY}

\section{PATHOLOGICAL BEHAVIORAL PATTERNS RELATED TO THE INTERNET IN A PERSON WHO USE PSYCHOACTIVE SUBSTANCES}

Stolyarenko A. N.

Zaporizhzhya State medical University, Ukraine

The involvement of people who use psychoactive substances in Internet use imposes certain behavioral changes on them. The combination of the psychopathological predispositional background in the form of emotional-volitional disorders with the phenomena inherent in the in-depth use of the Internet determines the development of specific behavioral patterns associated with Internet use in individuals of the studied group.

The purpose of the study is to investigate and systematize pathological behavioral patterns associated with the Internet in people who use psychoactive substances.

Material and research methods. To achieve the goal of the study, a content analysis of scientific literature and media materials was carried out, and 34 people with mental and behavioral disorders due to the use of psychoactive substances were examined (F19.2).

As a result of the study, five pathological behavioral patterns associated with the Internet in individuals who use psychoactive substances were identified and described: reduction of offline communication and preference for online leisure, Internet coverage of one's own asocial actions, change of addictive search activity from offline environment to the Internet, auto-induction of extreme drops moods with Internet content and Internet content inducing extreme behaviors.

Conclusions. Internet use can lead to a specific pathological modification of the behavior of people who use psychoactive substances. Identified behavioral patterns can cause an increase in social maladaptation and act as a potentiating and supporting factor in anesthesia.

Keywords: Internet, Internet use, Internet addiction, addiction to psychoactive substances, behavioral patterns.

\section{АВТОРСЬКА ДОВІДКА}

- Столяренко Андрій Миколайович, кандидат медичних наук, доцент кафедри психіатрії, психотерапії, загальної та медичної психології, наркології та сексології Запорізького державного медичного університету МОЗ України, м. Запоріжжя.

- Адреса: проспект Маяковського, 26, м. Запоріжжя, 69035.

- Телефон: +380505339662

- E-mail:anstolyarenko@gmail.com
- Столяренко Андрей Николаевич, кандидат медицинских наук, доцент кафедры психиатрии, психотерапии, общей и медицинской психологии, наркологии и сексологии Запорожского государственного медицинского университета МЗУкраины, г. Запорожье.

- Адрес: проспект Маяковского, 26, г. Запорожье, 69035.

- Телефон: +380505339662

- E-mail:anstolyarenko@gmail.com
- Stolyarenko Andriy, Ph.D., Associate Professor of the Department of Psychiatry, Psychotherapy, General and Medical Psychology, Narcology and Sexology, Zaporizhzhya State Medical University of the Ministry of Health of Ukraine, Zaporizhzhya.

- Address: 26, Mayakovsky Ave., Zaporizhzhya, 69035.

- Contact number: +380505339662

- E-mail:anstolyarenko@gmail.com 